WASH-1344

Distribution Category UC-4

\title{
A RECOMMENDED RESEARCH PROGRAM \\ IN GEOTHERMAL CHEMISTRY
}

October 1974

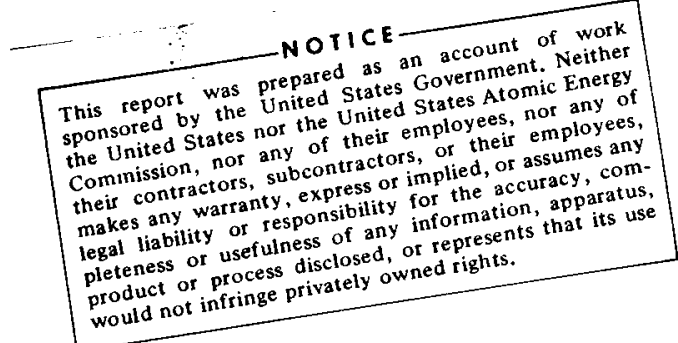

Prepared by

An Ad Hoc Committee

Convened by the

U. S. Atomic Energy Commission

with

Richard N. Lyon of the Oak Ridge National Laboratory

and

George A. Kolstad of the Division of Physical Research, AEC,

as

Cochairmen 


\section{DISCLAIMER}

This report was prepared as an account of work sponsored by an agency of the United States Government. Neither the United States Government nor any agency Thereof, nor any of their employees, makes any warranty, express or implied, or assumes any legal liability or responsibility for the accuracy, completeness, or usefulness of any information, apparatus, product, or process disclosed, or represents that its use would not infringe privately owned rights. Reference herein to any specific commercial product, process, or service by trade name, trademark, manufacturer, or otherwise does not necessarily constitute or imply its endorsement, recommendation, or favoring by the United States Government or any agency thereof. The views and opinions of authors expressed herein do not necessarily state or reflect those of the United States Government or any agency thereof. 


\section{DISCLAIMER}

Portions of this document may be illegible in electronic image products. Images are produced from the best available original document. 
CONTENTS

Introduction . . . . . . . . . . . . . . . . . . . . . 1

Summary of the Program ....................... 4

Members of Subprogram Panels . . . . . . . . . . . . . 5

Details of the Program:

I. Thermodynamic and Physical Properties of Geothermal

Solutions, Minerals, and Metals . . . . . . . . . . . 9

II. Kinetics . . . . . . . . . . . . . . . . . . 15

III. Collection, Evaluation, and Dissemination of Physical and Chemical Data... . . . . . . . . . . . 25

IV. Natural Systems and Rock-Water Interactions . . . . . . . . . 33

V. Theoretical Modeling of Geothermal Systems . . . . . . . . . 41 
A RECOMMENDED RESEARCH PROGRAM

IN GEOTHERMAL CHEMISTRY

\section{INTRODUCTION}

The geothermal resources in the United States have been estimated as capable of development to a capacity of at least 20,000 MW of elec-

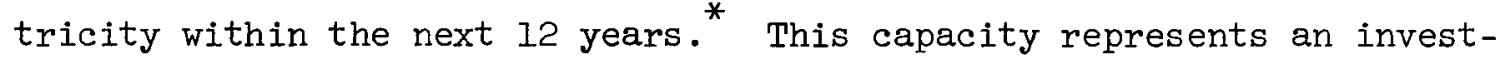
ment of more than $\$ 10$ billion, and a saving of $1.5 \times 10^{9}$ million Btu per year that would otherwise have to be supplied by other sources of energy. A capacity of $80,000 \mathrm{MW}$ is projected for the year 2000 and 200,000 MW for 2020 .

Exploitation of our geothermal resources is hampered, and in some cases blocked, by a number of problems that can be solved or eased by acquiring more chemical data, and by reaching a better chemical understanding of geothermal processes. On the instigation of the Division of Physical Research and the Division of Applied Technology of the U. S. Atomic Energy Commission, an Ad Hoc Group gathered on June 19 and July 22, 1974, at Lawrence Berkeley Laboratory to discuss those problems and to draw up and recommend a program for acquisition of the needed chemical data and knowledge. This report presents the resulting program.

The principal technological tasks that will benefit from this program are:

I. Control of corrosion
A. By geothermal fluids
B. By working fluids

II. Control of precipitation
A. In well casings
B. In pipelines
C. In vessels for conditioning geothermal fluids
D. In components of power stations

\footnotetext{
* "The Nation's Energy Future," a report to President Richard M. Nixon by Chairman Dixy Lee Ray of the U. S. Atomic Energy Commission, December 1, 1973.
} 
E. In space heaters and other components for nonelectric use of heat

F. In reinjection wells

III. Exploration, resource evaluation, and resource monitoring

IV. Selection and design for the use of working fluids

A. Chemical stability, toxicity, flammability, etc.

B. Solubility in geothermal water and brines

C. Thermodynamic and thermophysical properties

V. Environmental protection

A. Control of the release of detrimental fluids

B. Control of subsidence and small local earthquakes that may be occasioned by leaching and alteration of underlying strata

c. Control of the depletion or contamination of existing aquifers

VI. Recovery of valuable elements and compounds

The relative difficulty of each task depends on the conditions found at each site, and sometimes varies from well to well at a single geothermal resource. Similarly, the optimum detailed methods for accomplishing those tasks must be worked out for each situation. But the chemical principles that pertain, the types of chemical data needed, and the chemical, mechanical, and mathematical approaches that apply for accomplishing those tasks are largely the same for all geothermal resources.

For that reason, the program is drawn up on a fundamental scientific framework, rather than in terms of application or developmental problems. This approach concentrates on the roots of the technological problems and avoids artificial division of chemical research amon the developmental problems. In addition, it makes the recommendations more comprehensible to the physical chemists and geochemists whose job it will be to implement the effort. For example, the control of scale formation in well casings and heat exchangers depends on our understanding the solubility and modes of precipitation of mineral derivatives such as silica and calcium carbonate. Similar understanding is needed in evaluation of the geographical extent, the long-term thermal potential of a given hot aquifer, and in minimizing loss of porosity in the strata at the foot of a reinjection well. 
Since this program is largely aimed at obtaining fundamental data and understanding, its results have application beyond the exploitation of geothermal energy. Better understanding of aqueous chemistry, particularly at high temperatures, can have almost immediate application in other sectors of the power industry and in the chemical industry, and information gained from this program will provide new geological insight and additional methods for determining the nature of deep strata.

The group identified five general areas of needed effort:

1. thermodynamic and physical properties of geothermal solutions, minerals, and metals;

2. kinetics of chemical reactions and deposition;

3. collection, evaluation, and dissemination of physical and chemical data;

4. natural systems and rock-water interactions;

5. theoretical modeling of geothermal systems.

Small panels then met and formulated subprograms for each area. The total program, consisting of the five subprograms, is summarized in Table 1. Subsequent sections of this report consist of the reports of the five panels. The individual tasks of the subprograms are assigned priorities: Priority 1, those that are urgently needed for evaluation and exploitation of known geothermal resources; Priority 2, those that are needed for economic optimization of that exploitation; and Priority 3, those needed for exploration for new resources and for a broader general understanding of geothermal resources. Although to some extent this designation implies a priority in needed effort, it actually is more a statement of the time at which the results are needed. Delay in initiating the longer-range parts of this program can result in their becoming urgent later with a resulting less efficient, less reflective effort, a loss in the benefits of proper reservoir management, and elimination of other predictable and serendipitous benefits derived from a sound and broadly based scientific program. As with all research programs for practical applications, the proper distribution of effort will change and should be reviewed periodically as a result of both scientific and technological advances. 
Table 1. sumary of progrem

\begin{tabular}{|c|c|c|c|c|c|c|c|c|c|}
\hline \multicolumn{2}{|r|}{ Bcientiric area } & \multirow{2}{*}{$\begin{array}{l}\text { Prior1ty } \\
(1,2,3)\end{array}$} & \multirow{2}{*}{$\begin{array}{l}\text { Technology } \\
(A \text { or } D)\end{array}$} & \multirow{2}{*}{$\begin{array}{l}\text { Seientific } \\
\text { sector } \\
(I, \mathrm{X}, \mathrm{U})\end{array}$} & \multicolumn{2}{|c|}{$\begin{array}{c}\text { Errort } \\
\text { (se1entific manyears) } \\
\text { lst year } 5 \text { years } \\
\end{array}$} & \multicolumn{2}{|c|}{$\begin{array}{c}\text { Operating runds } \\
\$ 60,000 / \mathrm{ENY} \\
(\$ 1000)\end{array}$} & $\begin{array}{c}\text { Equ 1pment run } \\
\text { ( noo0) } \\
5 \text { years }\end{array}$ \\
\hline \multicolumn{7}{|c|}{$\begin{array}{l}\text { 1. Properties or solutions, minerala, } \\
\text { metals, and work1ne fluids }\end{array}$} & & & \\
\hline & A. Solutions & $\begin{array}{l}1 \\
2 \\
3\end{array}$ & $\begin{array}{l}A \& D \\
A \& D \\
D\end{array}$ & $\begin{array}{l}\text { H or } U \\
\text { H or } U \\
\mathbf{y} \text { or } U\end{array}$ & $\begin{array}{l}9 \\
5 \\
+\end{array}$ & $\begin{array}{r}31 \\
12 \\
+\end{array}$ & $\begin{array}{r}540 \\
300 \\
+\end{array}$ & $\begin{array}{r}1800 \\
720 \\
+\end{array}$ & $\begin{array}{r}125 \\
95 \\
+\end{array}$ \\
\hline & B. Minerals and Rocks & $\begin{array}{l}1 \\
2 \\
3\end{array}$ & $\stackrel{A}{A} \mathrm{D}$ & $\begin{array}{l}\text { y or } U \\
\text { in } U \\
\text { in or } U\end{array}$ & $\begin{array}{l}1.4 \\
1.2 \\
0.4+\end{array}$ & $\begin{array}{l}7 \\
6 \\
2+\end{array}$ & $\begin{array}{l}84 \\
72 \\
24+\end{array}$ & $\begin{array}{l}420 \\
360 \\
120+\end{array}$ & $\begin{array}{l}+ \\
+ \\
+\end{array}$ \\
\hline & C. Rock-solution-gas interactions & $\begin{array}{l}1 \\
3\end{array}$ & $A D$ & $\begin{array}{l}\text { y or } U \\
\text { y or } U\end{array}$ & $\begin{array}{l}8 \\
2\end{array}$ & $\begin{aligned} 36 \\
4\end{aligned}$ & $\begin{array}{l}480 \\
120\end{array}$ & $\begin{array}{r}2160 \\
240\end{array}$ & $\begin{array}{r}350 \\
50\end{array}$ \\
\hline & D. Isotopes and trace elements & 1 & A & $\mathbf{y}$ or $\mathbf{U}$ & 5 & 25 & 300 & 1500 & 200 \\
\hline & R. Bnersy conversion & $\begin{array}{l}1 \\
3\end{array}$ & $\mathbf{A}$ & $\begin{array}{l}\mathrm{I}, \mathbf{M}, \text { or } \mathrm{U} \\
\mathrm{I}, \mathbf{n}, \text { or } \mathrm{U}\end{array}$ & 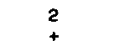 & 10 & $\begin{array}{r}120 \\
+\end{array}$ & $\begin{array}{r}600 \\
+\end{array}$ & $\begin{array}{l}0 \\
+\end{array}$ \\
\hline & F. Pure mater1als & $\underline{1}$ & $A \& D$ & $\mathbf{n}$ or $\mathrm{U}$ & 3.5 & 17.5 & 210 & 1050 & 100 \\
\hline & subtotals & $\begin{array}{l}1 \\
2 \\
3\end{array}$ & & & $\begin{array}{l}28.4 \\
6.2 \\
2.4+\end{array}$ & $\begin{array}{c}126.5 \\
18 \\
6+\end{array}$ & $\begin{array}{r}1734 \\
372 \\
144+\end{array}$ & $\begin{array}{c}7590 \\
1080 \\
360+\end{array}$ & $\begin{array}{l}775+ \\
95 \\
50+\end{array}$ \\
\hline \multirow[t]{5}{*}{ II. } & Kinetics & & & & & & & & \\
\hline & A. Above 60 bara and $275^{\circ} \mathrm{C}$ & 1 & D & $\mathbf{I}, \mathbf{n}$, or $\mathrm{U}$ & 5 & 25 & 300 & 1500 & 600 \\
\hline & B. 3 to 60 bars and 130 to $275^{\circ} \mathrm{C}$ & $\begin{array}{l}1 \\
2 \\
3\end{array}$ & $\stackrel{A}{A} \mathbf{D}$ & $\begin{array}{l}I, N \text {, or } U \\
I \text { or } Y \\
I, N \text {, or } U\end{array}$ & $\begin{array}{l}6 \\
1 \\
0\end{array}$ & $\begin{array}{r}40 \\
5 \\
15\end{array}$ & $\begin{array}{r}360 \\
60 \\
0\end{array}$ & $\begin{array}{r}2400 \\
300 \\
900\end{array}$ & $\begin{array}{r}500 \\
80 \\
150\end{array}$ \\
\hline & C. Below 3 bars and $130^{\circ} \mathrm{C}$ & $\begin{array}{l}2 \\
3 \\
\end{array}$ & 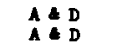 & 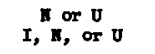 & $\begin{array}{l}2 \\
1 \\
\end{array}$ & $\begin{array}{l}10 \\
10 \\
\end{array}$ & $\begin{array}{r}120 \\
60 \\
\end{array}$ & $\begin{array}{l}600 \\
600 \\
\end{array}$ & $\begin{array}{r}80 \\
150 \\
\end{array}$ \\
\hline & aubtotals & $\begin{array}{l}1 \\
2 \\
3\end{array}$ & & & $\begin{array}{r}11 \\
3 \\
1\end{array}$ & $\begin{array}{l}65 \\
15 \\
25\end{array}$ & $\begin{array}{r}660 \\
180 \\
60\end{array}$ & $\begin{array}{r}3900 \\
900 \\
1500\end{array}$ & $\begin{array}{r}1000 \\
160 \\
300\end{array}$ \\
\hline \multirow[t]{5}{*}{ III. } & $\begin{array}{l}\text { Collection, evaluation, and dissemination } \\
\text { of phosical and chemical data }\end{array}$ & & & & & & & & \\
\hline & A. Collection & $\begin{array}{l}1 \\
2\end{array}$ & $\hat{A}$ & $\begin{array}{l}I, \mathbf{N}, \text { or } U \\
I, \mathbf{H}, \text { or } U\end{array}$ & $\begin{array}{l}4 \\
1\end{array}$ & $\begin{array}{r}10 \\
3\end{array}$ & $\begin{array}{r}240 \\
60\end{array}$ & $\begin{array}{l}600 \\
180\end{array}$ & $\begin{array}{l}0 \\
0\end{array}$ \\
\hline & B. Evaluat ion & 1 & $A \bullet D$ & I, $\mathbf{~}$, or $\mathrm{U}$ & 6 & 19 & 360 & 1140 & 0 \\
\hline & c. Disseatinat ion & 1 & A & n & $\underline{2}$ & 10 & 120 & 600 & 15 \\
\hline & subtotals & $\frac{1}{2}$ & & & $\begin{array}{r}12 \\
1\end{array}$ & 39 & $\begin{array}{r}720 \\
60\end{array}$ & $\begin{array}{r}2340 \\
180\end{array}$ & $\begin{array}{r}15 \\
0\end{array}$ \\
\hline \multirow{9}{*}{ N. } & Hatural syetens and rook-water interactions & $\cdot$ & & & & & & & \\
\hline & A. Analytic chemistry of natural materiale & $\frac{1}{2}$ & $A \notin D$ & $\begin{array}{l}\text { N or } \mathrm{U} \\
\text { in or } \mathrm{U}\end{array}$ & $\begin{array}{l}9.4 \\
0.6\end{array}$ & $\begin{array}{r}47.0 \\
3.0\end{array}$ & $\begin{array}{r}564 \\
36\end{array}$ & $\begin{array}{r}2820 \\
180\end{array}$ & 95 \\
\hline & $\begin{array}{l}\text { B. Technology of down hole sampling } \\
\text { and moasuring }\end{array}$ & 1 & $A \propto D$ & $I$ or $U$ & 3 & 15 & 180 & 900 & 250 \\
\hline & c. Gootherwal date & 2 & $\boldsymbol{A}$ & x ox 0 & \multicolumn{4}{|c|}{ (Provided for in other progreas) } & \\
\hline & D. Inotope studiea & $\frac{1}{2}$ & $\hat{A}$ & I or $\mathrm{I}$ & $\begin{array}{l}1.5 \\
1.0\end{array}$ & $\begin{array}{l}7.5 \\
5.0\end{array}$ & $\begin{array}{l}90 \\
60\end{array}$ & $\begin{array}{l}450 \\
300\end{array}$ & $\begin{array}{l}200 \\
200\end{array}$ \\
\hline & z. Bolla phase studies & $\begin{array}{l}1 \\
2 \\
3\end{array}$ & $A \stackrel{A}{A}$ & $\begin{array}{l}\text { I } \text { or } \\
\text { I } \text { or } \\
\text { I or }\end{array}$ & $\begin{array}{l}3.0 \\
3.0 \\
0.5\end{array}$ & $\begin{array}{r}15.0 \\
15.0 \\
2.5\end{array}$ & $\begin{array}{r}180 \\
180 \\
30\end{array}$ & $\begin{array}{l}900 \\
900 \\
150\end{array}$ & $\begin{array}{r}80 \\
150 \\
50\end{array}$ \\
\hline & I. Spocial experimental studies & 1 & A & I or $\mathbf{~ I ~}$ & 6.0 & 30.0 & 360 & 1800 & 300 \\
\hline & G. Maturally oceurring organic compounde & 3 & $\mathbf{A}$ & $\mathbf{I}, \mathbf{K}$, or $\mathrm{U}$ & 0.5 & 2.5 & 30 & 250 & 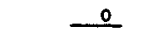 \\
\hline & Subtotals & $\begin{array}{l}1 \\
2 \\
3\end{array}$ & & & $\begin{array}{r}22.9 \\
4.6 \\
1.0\end{array}$ & $\begin{array}{r}114.5 \\
23.0 \\
5.0\end{array}$ & $\begin{array}{r}1374 \\
276 \\
60\end{array}$ & $\begin{array}{r}6870 \\
1380 \\
300\end{array}$ & $\begin{array}{r}95 \\
350 \\
50\end{array}$ \\
\hline \multirow{8}{*}{ v. } & Thooretical modeling & & & & & & & & \\
\hline & A. Aqueoul phases & 1 & $A \bullet D$ & n or U & 4.0 & 13.0 & 240 & 780 & 0 \\
\hline & B. Bolid wolutione and disordered phaser & $\frac{1}{2}$ & $A \notin D$ & $\begin{array}{ll}\text { or } \mathrm{U} \\
\text { or } \mathrm{U}\end{array}$ & $\begin{array}{l}0.6 \\
0.6\end{array}$ & $\begin{array}{l}3.0 \\
3.0\end{array}$ & $\begin{array}{l}36 \\
36\end{array}$ & $\begin{array}{l}180 \\
180\end{array}$ & $\stackrel{0}{0}$ \\
\hline & c. Caloulational prograe & $\frac{1}{2}$ & $\begin{array}{ll}A & \perp D \\
A & \perp D\end{array}$ & $\begin{array}{l}\text { I or } 0 \\
\text { or } 0\end{array}$ & $\begin{array}{l}0.5 \\
0.5\end{array}$ & $\begin{array}{l}2.5 \\
2.5\end{array}$ & $\begin{array}{l}30 \\
30\end{array}$ & $\begin{array}{l}150 \\
150\end{array}$ & $\begin{array}{l}0 \\
0\end{array}$ \\
\hline & D. theorical analye 10 & 1 & $A * D$ & or 0 & 0.8 & 4.0 & 48 & 240 & . \\
\hline & Subtotal & $\begin{array}{l}1 \\
2 \\
\end{array}$ & & & $\begin{array}{l}5.9 \\
1.1 \\
\end{array}$ & $\begin{array}{r}22.5 \\
5.5 \\
\end{array}$ & $\begin{array}{r}354 \\
66 \\
\end{array}$ & $\begin{array}{r}1350 \\
330 \\
\end{array}$ & $\begin{array}{l}0 \\
0 \\
\end{array}$ \\
\hline & TOTALS & $\begin{array}{l}1 \\
2 \\
3\end{array}$ & & & $\begin{array}{r}80.7 \\
15.9 \\
4.4+ \\
\end{array}$ & $\begin{array}{r}367.5 \\
64.5 \\
36.0+ \\
\end{array}$ & $\begin{array}{r}4842 \\
954 \\
264+ \\
\end{array}$ & $\begin{array}{r}22,050 \\
3,870 \\
2,160 . \\
\end{array}$ & $\begin{array}{c}2815+ \\
605 \\
400+ \\
\end{array}$ \\
\hline & & & & & $201.0+$ & $468.0+$ & $6060+$ & $28,080+$ & $3820+$ \\
\hline Motes: & 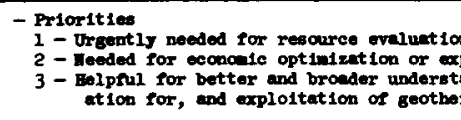 & $\begin{array}{l}\text { exploita } \\
\text { tation. } \\
\text { Ing of, exp } \\
\text { resources }\end{array}$ & & $\begin{array}{l}\text { - Technology } \\
\text { A - Avaliable } \\
\text { D - Requ 1rea }\end{array}$ & development & & $\begin{array}{r}\text { - Scient 1f } \\
\text { U - Un1v } \\
\text { I - Mat1 } \\
\text { I - Indu }\end{array}$ & $\begin{array}{l}\text { c sector } \\
\text { rsities } \\
\text { nal labora } \\
\text { try }\end{array}$ & ories \\
\hline
\end{tabular}


MEMBERS OF SUBPROGRAM PANELS

PANELISTS FOR SECTION I

Thermodynamic Properties of Geothermal Solutions,

Minerals, and Metals

$\begin{array}{lll}\text { Chairman: } & \text { Charles E. Holley } & \text { LASL } \\ \text { Members: } & \text { John P. Balagna } & \text { LASL } \\ & \text { Lawrence Blatz } & \text { LASL } \\ & \text { Robert Charles } & \text { LASL } \\ & \text { Roy Feber } & \text { LASL } \\ & \text { John L. Haas, Jr. } & \text { USGS - Reston, VA } \\ \text { Claude C. Herrick } & \text { LASL } \\ \text { William L. Marshall } & \text { ORNL } \\ \text { Robert E. Mesmer } & \text { ORNL } \\ \text { Clayton Olson } & \text { LASL } \\ \text { Kenneth S. Pitzer } & \text { LBL } \\ \text { John Ramsey } & \text { LASL } \\ \text { Cornell Wohlberg } & \text { LASL }\end{array}$


PANELISTS FOR SECTION II

The Kinetics Program

$\begin{array}{lll}\text { Chairman: } & \text { Theodore Vermeulen } & \text { LBL } \\ \text { Members: } & \text { Frank Dickson } & \text { Consultant } \\ & \text { William H. Duewer } & \text { LLL } \\ & \text { Harold C. Helgeson } & \text { LBL } \\ & \text { Gerhard Klein } & \text { LBL } \\ \text { A. D. K. Laird } & \text { LBL } \\ \text { Robert Lim } & \text { LLL } \\ \text { J. G. Liou } & \text { Consultant } \\ \text { Richard L. Miller } & \text { ANC } \\ \text { George A. Parks } & \text { Consultant }\end{array}$

PANELISTS FOR SECTION III

Collection, Evaluation, and Dissemination of Physical and Chemical Data

Chairman: John L. Haas, Jr. USGS - Reston, VA

Members: William Evans NBS

James R. Fisher USGS - Reston, VA

Bruce Hemingway USGS - Reston, VA

Sidney Phillips LBL

Richard A. Robie USGS - Reston, VA

Bert R. Staples NBS

Howard White NBS 
PANELISTS FOR SECTION IV

Natural Systems and Rock-Water Interactions

$\begin{array}{lll}\text { Chairman: } & \text { Alfred H. Truesdell } & \text { USGS - Menlo Park, CA } \\ \text { Alternate Chairman: } & \text { Harry R. Bowman } & \text { LBL } \\ & & \\ \text { Members: } & \text { John P. Balagna } & \text { LASL } \\ & \text { Frank Dickson } & \text { Consultant } \\ & \text { Robert O. Fournier } & \text { USGS - Menlo Park, CA } \\ & \text { Alvin J. Herbert } & \text { LBL } \\ & \text { Everett H. Jenne } & \text { USGS - Menlo Park, CA } \\ & \text { Michael Thompson } & \text { USGS - Menlo Park, CA }\end{array}$

PANELISTS FOR SECTION V

Theoretical Modeling of Geothermal Systems

$\begin{array}{lll}\text { Chairman: } & \text { Kenneth S. Pitzer } & \text { LBL } \\ \text { Members: } & \text { Harold C. Helgeson } & \text { LBL } \\ & \text { Charles C. Herrick } & \text { LASL } \\ & \text { Paul A. Witherspoon } & \text { LBL }\end{array}$


ㄱ.

A 
I. THERMODYNAMIC AND PHYSICAL PROPERTIES OF GEOTHERMAL SOLUTIONS, MINERALS, AND METALS (INCLUDING SOURCES OF PURE MATERIALS)

\section{Introduction}

A knowledge of the thermodynamic and physical properties of materials is a requirement for the efficient engineering design and evaluation of any geothermal system. Thermodynamic properties are needed in order to predict (1) the flow of heat through the system, and (2) the reactions of the various components of the system with each other, including solubilities and corrosion. The physical properties required include thermal conductivities of rocks and brines, electrical properties of rocks and brines, viscosities of brines, and porosity and permeability of rocks.

Since the number of materials and combinations of materials is large, it is impractical to make detailed measurements on all of them. Theories or models, based on a relatively few key measurements and which can then be used for prediction, must be developed. Key measurements should be made on properly characterized materials; thus, a section of this report is included to discuss sources of pure materials.

Considerable information currently exists on the thermodynamic and other properties of common materials at ordinary temperatures and pressures. However, the pressure-temperature range of interest to geothermal energy extends to 1000 bars and $700^{\circ} \mathrm{C}$, and in the domain further away from ordinary temperatures and pressures less information is available. For the immediate future, data up to $400^{\circ} \mathrm{C}$ and 500 bars are the most urgentiy needed.

\section{$\underline{\text { Problem Areas }}$}

The collection, evaluation, and dissemination of available data is discussed in Section III. Experimental thermodynamic data are required for the most important components or systems, and the theoretical or empirical models must be improved to permit extrapolation by analogy with known systems.

\footnotetext{
*The maximum temperature may be above $1650^{\circ} \mathrm{C}\left(\sim 3000^{\circ} \mathrm{F}\right)$ if direct heat recovery from molten volcanic magma is pursued.
} 


\section{A. Properties of geothermal solutions}

Over the pressure-temperature range of interest ( 0 to 1000 bars and 0 to $700^{\circ} \mathrm{C}$, and more immediately 0 to 500 bars and 0 to $400^{\circ} \mathrm{C}$ ) insufficient data are available for solutions containing mixtures of the salts found most commonly in natural systems. Data are most urgently needed for systems containing the following species: $\mathrm{Na}^{+}, \mathrm{K}^{+}, \mathrm{Ca}^{2+}, \mathrm{Fe}^{2+}\left(\mathrm{Fe}^{3+}\right)$, $\mathrm{Cl}^{-}, \mathrm{SO}_{4}{ }^{2-}, \mathrm{HCO}_{3}$; and $\mathrm{SiO}_{2}(\mathrm{aq})$. Pressure-volume-temperature data (densities, vapor pressure, or osmotic coefficients), enthalpies, heat capacities, viscosities, thermal conductivities, electrical conductivities, and pertinent transport properties are needed. The electrical properties include electrical conductivity and dielectric constant measurements.

\section{B. Properties of minerals and rocks}

An evaluation of currently available data will show for which minerals of importance fundamental data such as thermodynamic properties, thermal conductivities, and porosities are absent, inadequate, or cannot be estimated with confidence.

More information is needed about the identity of the minerals commonly found in geothermal systems and their range of solid solutions in order to select candidates for calorimetric measurements. At this time, it is evident that calorimetric data are conspicuously lacking for layer lattice minerals, zeolities, epidotes, and feldspar glasses.

In the case of the zeolites, calorimetric measurements should be made to determine the enthalpy for the waters of hydration with the aim of helping in the development of a satisfactory bonding model for these waters. For the chlorites and the clays, the objective is to help in the development of a site-mixing model. For the hedenbergite and pargasiteferropargasite, estimates have been made and experiments are needed to check them.

\section{Rock-solution-gas interactions}

For a proper interpretation of experimental observations in rocksolution-gas systems, the characterization of thin films of secondary minerals formed on rock surfaces is crucial. In addition to the classical 
techniques of analysis of bulk properties, such as $x$-ray diffraction and petrography, the more recently developed surface-sensitive techniques, such as Auger Electron Spectroscopy (AES), low Energy Electron Diffraction (LEED), and Electron Spectroscopy for Chemical Analysis (ESCA), have a high potential for this purpose.

Measurements are needed at high temperatures and pressures (particularly in the range 100 to $400^{\circ} \mathrm{C}$ at the vapor pressure of the solution) to determine

1. mineral solubilities,

2. equilibrium constants for hydrolysis and base exchange reactions, and 3. the identity of aqueous species.

D. Isotopes and trace elements

Laboratory determination of distribution coefficients for isotopes of a given element between coexisting phases and between species in a homogeneous phase as a function of temperature is of great value for geochemical prospecting and for geothermometry. The stable isotopes of carbon, oxygen, hydrogen, and sulfur have been most useful to date and merit more work.

\section{E. Energy conversion}

The high solids content of the geothermal fluids makes consideration of unconventional heat removal systems, such as liquid-liquid exchangers, attractive. Information on the properties of low-boiling fluids affecting the thermodynamic efficiencies in power-producing cycles of "binary systems" that utilize heat exchangers is needed. The chemical stability and interactions of such substances with the working fluid and rock heat reservoir need to be studied.

\section{F. Pure materials}

For laboratory measurements, particularly of thermodynamic properties, sources of reasonable quantities of pure, or at least well characterized, materials of geologic interest must be available. Each reference material should have uniform composition and properties and be available in sufficient quantity to permit the widest possible variety of property measurements by a number of laboratories. To meet such a requirment over a 
period of time, it would be desirable to supplement available sources of natural minerals with a dependable source of reproducible artificial minerals for distribution upon request. Selected artificial minerals have been prepared by a few laboratories only in sufficient quantity to meet their individual immediate needs. The techniques used should be developed further to meet the larger needs and made available to the geothermal scientific community as a public service. 
Tuble I-1. Therwodynnule needs for geothermal chenistry

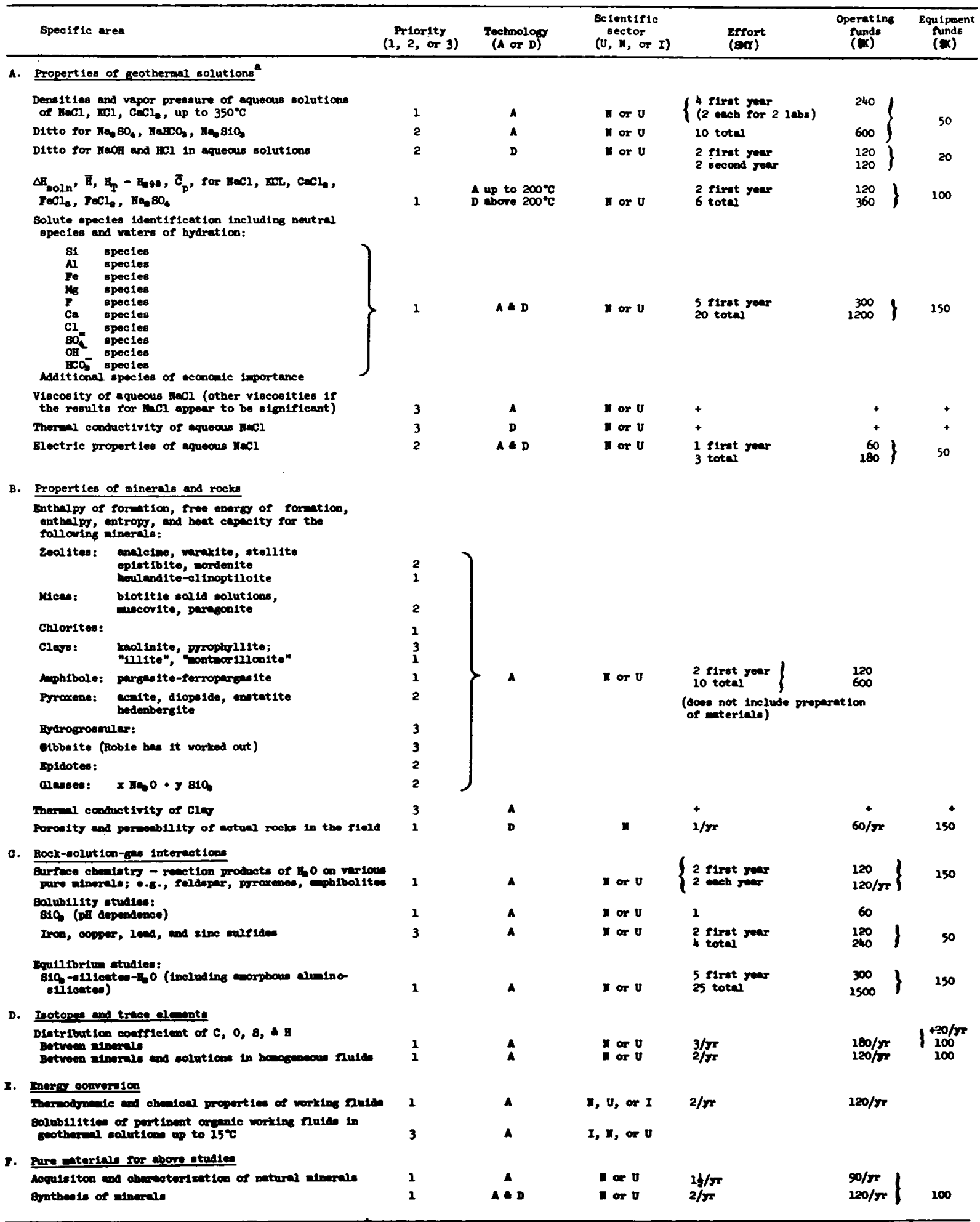

Unleas otberrice apecified it is understood that all the propert lea are to be coverured

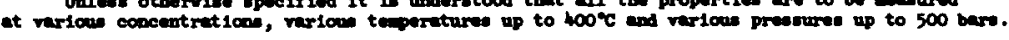


0

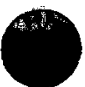




\section{KINETICS}

\section{Introduction}

Kinetics implements thermodynamics by identifying the extent to which theoretically possible effects will actually occur. Kinetics involves (I) experimental studies at simulated field conditions with complex materials, and also at idealized test conditions with model compositions; (2) correlation of experimental studies; and (3) prediction of field behavior. Field behavior of geothermal systems comprises (a) the producing reservoir, where chemical factors affect the physical geology; (b) the well proper; (c) above-ground handling and the power-plant system; (d) underground reinjection, either into the geothermal zone or into a disposal area; and (e) loss of gaseous components to the atmospheres.

Kinetic problems in geothermal-fluid systems largely involve one or more solid phases or surfaces in addition to the fluid phase. Many relevant model-component systems have been studied, but usually not over the entire range of conditions and time scales expected to be of importance in actual energy-producing systems.

A five-year time scale is projected for an intensive study. The main focus of each project should be directed toward generalizations widely applicable to geothermal power systems, even when a project is especially applicable to an individual well-defined system. This program should lay the groundwork for solving operational problems on future power systems, even though it will not be able to eliminate entirely the need for particular studies concerning each new location.

The studies needed are classified here by range of temperature and pressure, corresponding to differences in experimental complexity and also in a general way to differences in the geographic zone of their applicability: below ground, in the well and power plant, and in a brinedisposal facility. 


\section{Extreme Temperature-Pressure Range (over 60 bar and $275^{\circ} \mathrm{C}$ )}

Dissolution and precipitation studies at extreme conditions will utilize much the same apparatus and techniques of measurement. The solutions needed for precipitation tests will usually be prepared by hightemperature dissolution of either laboratory chemicals, single minerals, or representative rock samples. Likewise, the aqueous feed for dissolution tests may often contain a substantial extent of predissolved solutes.

Rate data may be obtained in either batch, staged flow, or "linear flow" systems. Emphasis should be placed on "point" values of the rate as a function of composition, temperature, pressure, agitation or flow conditions, surface-chemical nature of solids present, interfacial area, chemical driving force (which accounts for equilibrium limits, consecutive reactions, etc.), and catalytic or inhibitory materials present. Composition measurements on the aqueous phase should include determination of materials held in colloidal form. The temperature dependence of the rate processes requires particular attention, since in many cases the reservoir processes will be so slow that the laboratory studies must infer, rather than duplicate, their precise behavior.

A suggested apparatus and procedure for representative experiments in this area is given in Table II-1. Important outputs of the total research program will include the design of superior apparatus, and more complete definition and control of the experimental conditions.

\section{Dissolution processes}

1. Hot dry rock. Controlled fissuring on a large scale is an essential step in HDR operation. Water, as the favored working fluid in the engine cycle, will tend to dissolve exposed rock areas along a fissure. Although such dissolution will tend to enlarge the fissure, the rate of rock dissolution is believed to be higher under augmented mechanical stress, posing the possibility of selectively removing the rock wedges that serve to keep the fissure open. Fission evolution under stress, by dissolution, should therefore be modeled, and a search made for aqueous feeds that will generally optimize a fissure configuration. 
Table II-l. Outline of typical experiments

Extreme temperature-pressure range

(dissolution or precipitation)

Objective

To determine the rate of solution per unit rock area as a point function of solution composition, temperature, and rock history. Experiments should be conducted at two or more temperatures above the temperature of interest, in order to achieve results in reasonable time that would be indicative of slower underground processes by extrapolation based on apparent activation energy .

Reaction components

Uniform-size ground rock (in single mineral) having same average composition as bulk rock (or mineral) from which it was taken.

Distilled water.

Reagent-grade chemicals except for rock itself.

Destrable apparatus features and instrumentation

Liquid-level indication to obtain solution density.

Pressure measurement.

Temperature control to $\pm 1{ }^{\circ} \mathrm{C}$.

Alloy vessel chemically resistant to solutions used, to minimize catalytic effect of dissolved metal.

Provision for agitation of reproducible intensity at one or more levels.

Provision for take-off of small filtered samples.

Provision for transfer of filtered liquid to or from a second similar vessel at a separately controlled temperature.

Provision for input of $\mathrm{CO}_{3}, \mathrm{O}_{3}$, or other gas.

Device for applying a known high compressive stress to a small layer or bed of ground rock through which liquid can pass under forced flow.

Work-up of a run

Vapor-phase analyses for $\mathrm{CO}_{3}$ lost from rock.

Material balance between loss of solid. weight and invrease of solution content, extending if possible to a material balance on each chemical element present.

Characterization of colloidally dispersed material.

Plotting of a conversion-time curve from which point rates can be obtained by differentiation.

For maximum generality of the results, considerable emphasis should be placed on a mechanistic interpretation; data should be taken at least partly to support that purpose. 
2. Wet-rock reservoir in near-steady-state operation. Petrochemical effects in the evolution of a producing reservoir should be understood sufficiently to interpret the below-ground behavior. In particular, any potential changes in the quantity and type of solute material in the brine reaching the power plant should be predicted, and actual changes should be monitored and interpreted, in terms of estimated below-ground positiontime-temperature-composition curves. Experimental data on the rates of dissolution of the rock type or types known to be present in different producing reservoirs, under simulated reservoir conditions, are needed in order to complete these below-ground estimates. Because rock often dissolves partially rather than completely, dissolution at higher temperatures is governed by diffusion rather than by chemical reaction rates as such.

\section{Precipitation processes}

Both in hot-dry-rock operation and in conventional geothermal reservoirs, formation blockage by precipitation of solids from the brine may occur along the flow path. This may be critical to the reservoir operation if it occurs near the inlet of a producing well - or near the outlet of a reinjection well, as is possible in hot-dry-rock operation.

Silica and silicates generally increase in solubility with increasing temperature. Calcite $\left(\mathrm{CaCO}_{3}\right)$ and anhydrite $\left(\mathrm{CaSO}_{4}\right)$ decrease; but, for calcite, pressure effects including specifically the $\mathrm{CO}_{2}$ pressure, which controls the bicarbonate-carbonate equilibrium, can override the effects of temperature change.

Moderate Temperature-Pressure Range (from 3 to 60 bar and between 130 and $275^{\circ} \mathrm{C}$ )

Precipitation in well casing and power plant

Depending on the mineral content of the reservoir zone, the prevailing solids content of the produced brine will often be silicate but may alternatively be carbonate, sulfide, sulfate, or hydroxide; each of these poses the need for different in-plant techniques to avoid apparatus fouling. Physical and chemical methods for either accelerating or retarding solids deposition will provide the means of controlling where 
where deposition does occur, in such a way that susceptible plant components are rather fully protected.

1. Nucleation. Iiquid-phase and interfacial nucleation may be almost equally important above ground, whereas interfacial effects probably govern precipitation below ground. In turn, the liquid-phase behavior itself may be homogeneous, or it may be heterogeneous with respect to colloids or dispersed fine particulates formed below ground.

Silicic acid and silicates, at times, may possibly follow the kinetics of condensation polymerization, rather than the normal kinetics of crystal nucleation and growth. Other solids formed from geothermal brines are likely to be more "normal." Nucleation can sometimes be inhibited by adducts, e.g., surfactants, which block the growing clusters and stabilize them; whether blockage of silicate chains is possible remains to be determined. Acceleration of nucleation and crystal growth is often achieved by rapidly precipitable foreign materials which substitute for the solid state of the main precipitating compound, as a base for crystal growth. Alternatively, addition of seed crystals in large number to a brine will circumvent the nucleation step and lead immediately to crystal growth on the seeds. These factors should all be investigated for the silicates and other compounds which are likely to precipitate from brines.

2. Hydrodynamic and bulk-solid-surface effects. Deposition in well casings is known to be favored by eddy zones attached to abrupt changes in pipe diameter. Also, different solid surfaces appear to have different degrees of attraction for growing nuclei. Hence, attachment of solid to equipment surfaces is strongly dependent upon both the composition and shape of the containing vessel.

All the factors enumerated in paragraphs 1 and 2 should be investigated for silicates and other compounds that are likely to precipitate from brines.

Consequences of brine disposal or reinjection

Subsequent to passage through the power-generating step, the geothermal brine must be treated further to make it acceptable environmentally and chemically in the discharge mode. In some cases, a different water will be injected. and the original brine will be utilized or 
discarded in an unrelated way. When reinjected brine reaches any particular aquifer, it is desirable that precipitation should not occur in the mixing zone, by any reaction either with the water layer or with the containing formation.

Dissolution of rock into the depleted brine may be a significant factor in the effectiveness of the reinjection. Gradual opening-up of a receiving formation might conceivably begin to allow reinjected brine to reach a different destination than the intended one. Also, a reinjection intended to reach the geothermal reservoir zone could arrive there with a solute composition that would alter the preexisting behavior in regard to dissolution and/or deposition. Kinetic studies in this category will identify the need for brine posttreatment. The treatment itself is covered in the next section.

\section{Dissolution of well-casing cements}

The high temperatures expected in geothermal wells, and the wide range of possible brines compositions, brings into question the chemical stability of casing cements. A modest experimental program to evaluate the relative durability of different cements under representative well conditions could lead to a more knowledgeable selection of the cement for any given well.

\section{Corrosion and erosion}

Existing installations for geothermal power production have had varied experience in regard to corrosion. Sulfide, chloride, and residual acidity or alkalinity are the principal corrosive agents. Erosion of piping elbows, turbine blades, pump impellers, and other plant components may be caused by suspended solids, including those freshly formed by precipitation. In many cases, the primary control of corrosion lies in the choice of suitably resistant materials of construction; in others, the most economic solution is a plan for scheduled replacement of plant components.

Table II-2 gives a commonly used classification of corrosion types, all of which are potentially important in geothermal energy utilization. Systematic general corrosion tests should be carried out using both simulated and actual brines over the entire temperature range of interests. 
Table II-2. Types of corrosion of interest in geothermal energy utilization

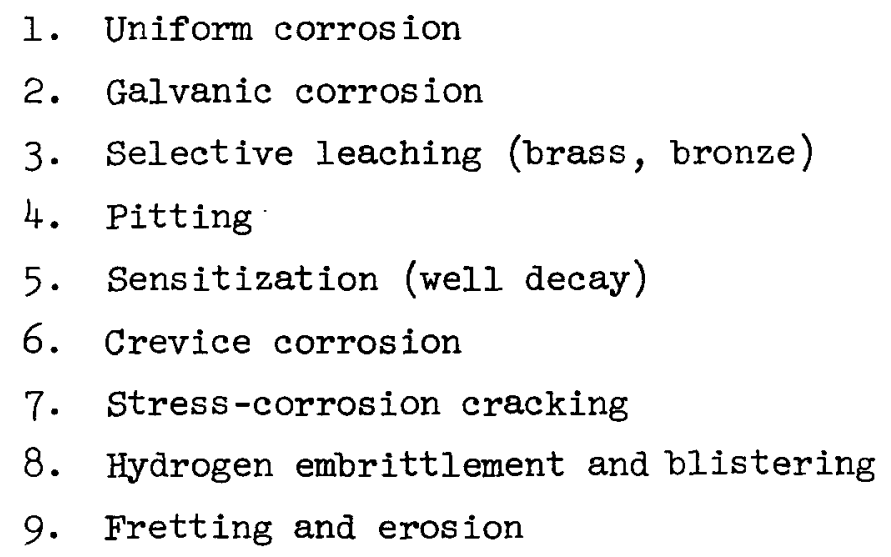

(Subsequently, it is expected that each demonstration plant and operating plant would conduct its own long-term surveillance of corrosion samples.) In the tests, coupons of candidate materials would be mounted in a throughflow assembly, in tests of one-year or longer duration. Joining methods such as welding, riveting, and bolting, stressed samples, crevice samples, and specimens of potential galvanic couples should be included. Examination of the specimens should include surface loss or modification, pitting, hydrogen embrittlement, and hydrogen blistering.

\section{Near-Amient Conditions (under 3 bar and $130^{\circ} \mathrm{C}$ )}

\section{Modeling of higher-temperature processes}

The principles of the chemical and physical effects attending precipitation and dissolution can be studied efficiently under near-ambient conditions. For example, the chemical and diffusional rates of precipitation at elevated temperatures will often be describable by direct extrapolation of lower-temperature data. The influence of hydrodynamic effects can be generalized by ambient-condition studies on precipitation systems chemically different from the actual brine reactions. The conception and demonstration of suitable models is itself part of such research. For example, a strongly compressed bed of rock salt, or of some other soluble 
solid, might simulate the much slower deterioration of hot-rock fissures through which brine is flowing.

Predisposal or preinjection treatment of brine

Studies to establish the need for reducing or otherwise altering the solute composition of a brine, after it has let the power-generating step, are discussed above (in "Moderate Temperature-Pressure Range"). Spontaneous precipitation of solids from a brine should u.sually be allowed to go to completion before the brine leaves the plant site, in order to avoid delivering a slurry at the disposal point. Research on brine-treatment methods, such as ion exchange or precipitation, must await identification of the specific disposal problems. 
Appendix II-1

FUNDAMENTAL VS APPLIED RESEARCH

Research done for purposes of correlation and prediction, or for development and demonstration of new apparatus and new experiment techniques, can be considered "fundamental." Work done on brines or rocks obtained at a single active or prospective geothermal site will usually be "applied," unless the laboratory runs are made in parallel with runs on pure materials and involve tests of correlation-prediction procedures that are being developed. 
Table II-3. Kinetics

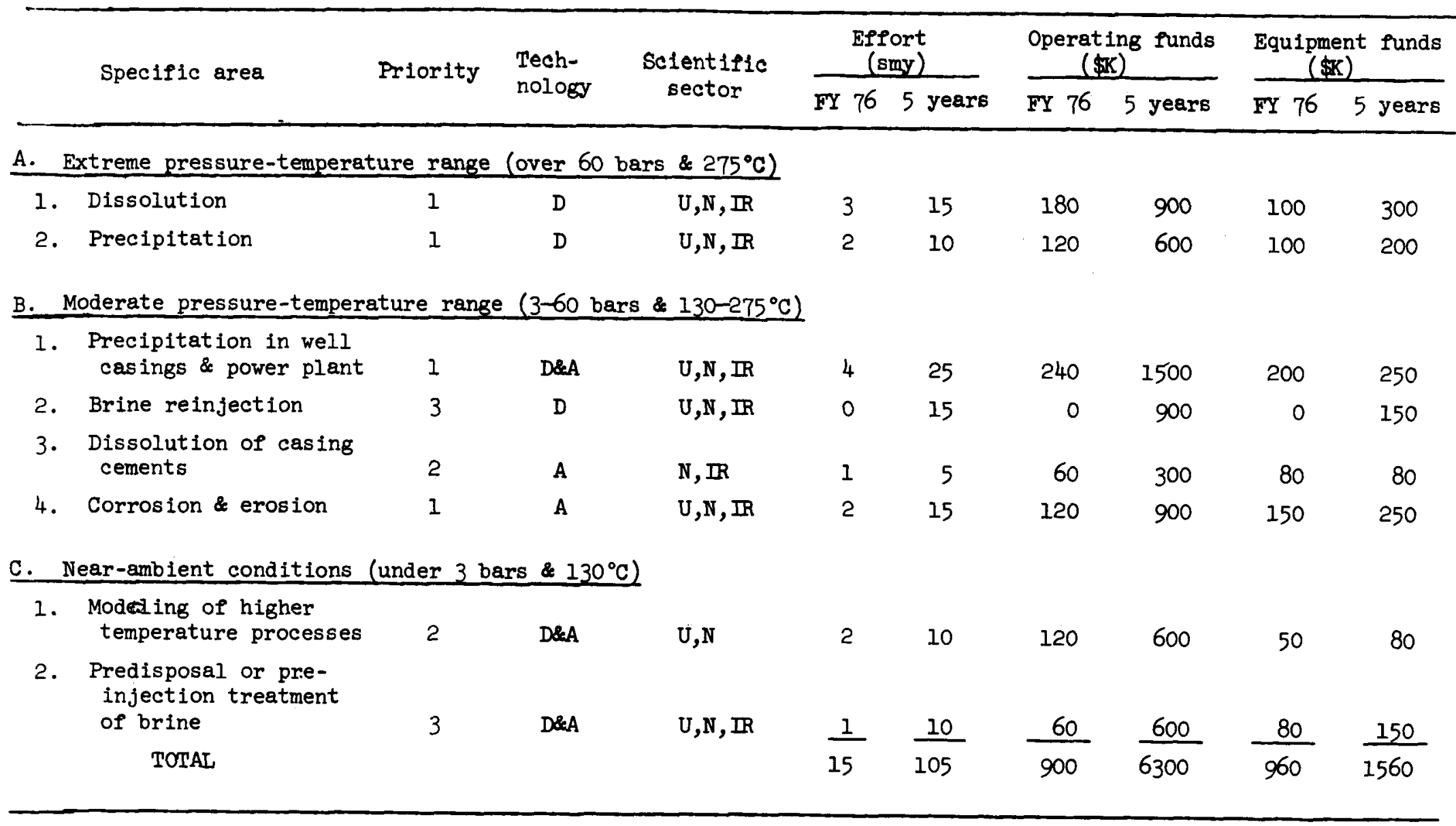


III. COLLECTION, EVALUATION, AND DISSEMINATION OF

PHYSICAL AND CHEMICAL DATA

\section{Introduction}

In high-temperature aqueous chemistry and in the geological sciences there is a wealth of poorly evaluated experimental data. In this new venture in chemical research, "geothermal chemistry," and integrated program for collection, evaluation, and dissemination of these data will produce considerable savings because the cost of such an integrated program is less than 5\% of the cost of duplicating the original experimental research needlessly. If a prompt and adequate effort is made here, the scientists and engineers working on the geothermal chemistry program will be able to work more effectively. They will have a ready source of interpreted and evaluated data from the published literature. The compilations developed for the scientists and engineers will locate and assemble the useful data that are available and will enable them to understand the problem, to specify the data that the engineer will need to solve the problem, and to define areas where the scientists can most economically and fruitfully expand the available body of data and knowledge.

\section{Status of Available Compilations}

There are many compilations of data but no one compilation nor any group of compilations contain the data needed for the proper utilization of the geothermal resources. Some compilations are extensive but are only of marginal interest because of the limited scope. Examples are the reports of the National Standard Reference Data System. These are often extensive in content but restricted to $25^{\circ} \mathrm{C}$ and one atmosphere (cf. NBS Technical Note 270) or extensive in temperature but limited in content and restricted to one atmosphere (cf. JANAF Tables). Mineralogical thermochemistry has not been updated with any systematic effort since the publication of the U. S. Geological Survey's Bulletin 1259 in 1968, and that effort was primarily an evaluation of calorimetric data.

With support, the densities of minerals can be derived from the extensive files of the Joint Committee on Powder Diffraction Standards, though 
these data will not be supplied automatically. The elastic constants for minerals and calculated aggregate properties were recently reviewed by Gene Simmons and Herbert Wang in Single Crystal Elastic Constants and Calculated Aggregate Properties published by the Massachusetts Institute of Technology in 1971. Other compiled data on the elastic constants and on the thermal and electrical conductivities of rocks and minerals are contained in Special Paper 97 of the Geological Society of America which was published in 1966.

F. J. Millero reviewed the data on electrolytes and calculated the partial molal volumes of solutes for many electrolytes of interest to the geothermal program in the temperature range 0 to $200^{\circ} \mathrm{C}$. These data are contained in Water and Aqueous Solutions edited by R. A. Horne and published in 1972. However, this survey contains only the very accurate data from which molal volumes could be calculated. Density data of lower accuracy are not included. Data for vapor pressures of solutions of interest to the geothermal program have not be systematically evaluated.

In summary, some collections of references and data exist and are either current or reasonably current. The major exception is the data for the thermodynamic properties of minerals and of dissolved constituents in water at elevated temperature and pressure. Collections are maintained by data centers for other purposes. Without support, these data centers cannot undertake the special evaluations needed and still accomplish their primary tasks.

\section{Problem Areas}

The following problem areas have been specifically identified. They are presented in the order of attack and no significance as to priority is attached here.

Coordination is needed for an effort that will be scattered throughout many sectors and physical locations, and that must coordinate the effort with that of groups doing exploration, research, and theoretical modeling. This is the logical location for such a position since the marager is most familar with the active projects and their successes or fajlures: 


\section{A. Collection of data}

1. The reservoir mineralogy. The identity of minerals, which should be expected in a geothermal reservoir, $i$ not readily available. This information is fairly common knowledge in geological sciences but to the nongeologist this is largely a mystery. And because most of the naturally occurring silicates, which comprise the bulk of the rock, are complex solid solutions, the mineral's name does not define the chemistry uniquely. If only as a guide to the bibliographer and to the evaluator of data, a review of the mineralogy of known thermal reservoirs is needed. (The composition of underground waters are adequately described in the U. S. Geological Survey's Professional Paper 440F, published in 1963, and in a recent review by $I$. Barnes and J. D. Hem, which is published in the Annual Review of Earth and Planetary Sciences, Volume 1, 1973.)

2. Thermodynamic data. With the reservoir mineralogy and the composition of underground waters as an immediate guide and the elements given in the introduction as an overall guide, brief annotated bibliographies should be prepared for use in the detailed evaluation of thermodynamic data. The extensive, unevaluated files of the National Bureau of Standards and the files of the U. S. Geological Survey will serve as a beginning upon which to build.

3. Thermophysical data. Included here are the transport properties: viscosity, thermal conductivity, and electrical conductivity, acoustical impendence, and also magnetic susceptibility. Recent compliations are generally available. These need to be updated so that they are current.

\section{B. Evaluation}

Attention should be given to methods for the evaluation of thermodynamic data. The functional relations among the thermodynamic variables must be satisfied and faithful recalculation of the experimental source data within the observational errors must be met by the refined thermodynamic variables. The high accuracy for much of the data is needed because the data will be used in model studies upon which economic decisions will be made. 
1. Method for estimation. A concise guide on methods for estimation of data needed in geothermal resource utilization is needed. As with any program at the frontier of science, reliable experimental data are unavailable. Here, coordination is necessary with the theoretical model studies, in section $\mathrm{V}$, to insure a scientifically and economically integrated program.

2. Evaluation of data. A systematic review and critical evaluation of the bibliographies should be performed to obtain:

a. The pressure-volume-temperature-composition data for solutions . These results should be consistent with the known densities, thermal expansivities, and compressibilities. After the initial "catch-up" phase, this area would be automatically covered by item $c$, which deals with thermodynamic correlations.

b. The pressure-volume-temperature-composition data for minerals . Again the agreement with densities, thermal expansivities, and compressibilities is needed but is not as critical as for solutions. After the initial "catch-up" phase, this area would be automatically covered by item d, which deals with thermodynamic correlations.

c. The thermodynamic functions for water and the solutes in water. The results must satisfy the functional relations among heat capacity, entropy, enthalpy, and free energy as well as the state variables of pressure, volume, temperature, and composition. The functions must also satisfy the known data for isochemical inversions and for chemical reactions among the phases in the chemical system given in the introduction. Every test upon the thermodynamic functions for internal consistency increases the probability of obtaining accurate data and decreases the cost of engineering.

d. The thermodynamic functions for minerals. The constraints are the same as item $c$ above.

e. The viscosity of solutions and natural gas mixtures.

f. The thermal conductivity of minerals, of the water-rich solutions and of the rock-water aggregate. These data are needed in model studies bearing upon the efficiency of energy extraction. 
g. The electrical conductivity, accoustical impedence, and magnetic susceptibility of the minerals, the water, and the rock-water aggregate. These data contribute to improved techniques for geophysical exploration.

h. The isotopic equilibria among minerals and among mineral-water mixtures. These data are used to evaluate the subsurface temperatures in a hot spring area and to monitor the hydrology where more than one aquifer is present.

\section{Dissemination}

The results of this effort will be used by many studies and for quite different purposes. Consideration of the method for dissemination should be included. In general, provision for hard copy, for microfilm copy, and for remote access to an "on-line" computer file should be considered. To be of maximum use the results of the evaluation should be in a form useful to the researcher as well as the engineer.

Similar data programs are improved if all requests are made at one location. There the user can be quickly apprised of the status of the data sought. Where the primary data are unavailable, data for related materials might be supplied or best methods for estimation might be suggested.

Because the geothermal research is already underway and decisions must be made even while the bibliographies are being assembled, there is a real need for unevaluated, but annotated bibliographies. As part of the effort of collecting the data, these should be prepared and disseminated upon demand.

Both the researcher and the engineer need tabulated data including a measure of accuracy and, if available, algebraic constants for fitted theoretical or empirical functions again including a measure of accuracy. In addition, most researchers and some engineers would have need for the references used in the derivation of tabulated data. Because annotated lists of references used in the evaluation must be kept in expectation of new data, the furnishing of the references cited in the evaluation should be no major concern. 
Table of Needs for Collection, Evaluation, and Dissemination of Physical and Chemical Data

Table III-I contains the estimated needs to begin and maintain a viable effort for collection, evaluation, and dissemination of published and available unpublished data to the industrial and scientific community concerned with geothermal resources.

The estimated priorities are based upon:

1. The need to accomplish the task prior to other important research.

2. The contribution that the task will make to the effort.

The effort is based upon accomplishing $1 / 2$ to $2 / 3$ of the backlog the first year and the balance of the backlog as well as maintaining current files in the subsequent four years. These efforts and operating funds are intended to augment existing data collection centers to perform the desired tasks. If new centers are established without utilization of ongoing effort in related fields, the efforts and costs here should be doubled.

Some savings in the first year efforts can be achieved. Particularly those efforts marked by astarisk (*) could be reduced or eliminated by proper coordination with efforts contained in other reports. For example, any intelligent effort to measure fluid viscosities experimentally must be prefaced by a review and evaluations of previous research. Coordination with such initiated research efforts removes the need for further evaluation here. 
Table III-1. Collection, evaluation, and dissemination of physical and chemical data

\begin{tabular}{|c|c|c|c|c|c|c|c|c|c|}
\hline \multirow{2}{*}{\multicolumn{2}{|c|}{ Specific area }} & \multirow{2}{*}{$\begin{array}{l}\text { Priority } \\
\text { (1 thru 3) }\end{array}$} & \multirow{2}{*}{$\begin{array}{c}\text { Technology } \\
(A \text { or } D)\end{array}$} & \multirow{2}{*}{$\begin{array}{c}\text { Scientific } \\
\text { sector } \\
\text { (U, N, or I) }\end{array}$} & \multicolumn{2}{|c|}{$\begin{array}{l}\text { Effort } \\
\text { (SMY) }\end{array}$} & \multicolumn{2}{|c|}{$\begin{array}{l}\text { Operating funds } \\
\qquad(\$ K)\end{array}$} & \multirow{2}{*}{$\begin{array}{l}\text { Equipment } \\
\text { funds } \\
\text { (\$K) }\end{array}$} \\
\hline & & & & & lot year & 5 years & lst year & 5 years & \\
\hline \multirow[t]{4}{*}{ A. } & Collection of data & & & & & & & & \\
\hline & 1. The reservolr mineralogy & 1 & A & $\mathrm{U}, \mathrm{N}, \mathrm{I}$ & 1 & 1 & 60 & 60 & \\
\hline & 2. Thermodynamic data & 1 & A & N & 3 & 9 & 180 & 540 & \\
\hline & 3. Thermophysical data & $2(1)$ & $A$ & $\mathrm{U}, \mathbf{N}, \mathrm{I}$ & 1 & 3 & 60 & 180 & \\
\hline \multirow[t]{11}{*}{ B. } & Evaluation & & & & & & & & \\
\hline & 1. Methods of estimation & 1 & $A(D)$ & $\mathrm{U}, \mathrm{N}, \mathrm{I}$ & 1 & 2 & 60 & 120 & \\
\hline & 2. Evaluation of data & & & & & & & & \\
\hline & a. $p-v-t-x$ of solutions & 1 & A & $\mathrm{U}, \mathrm{N}, \mathrm{I}$ & $1^{*}$ & $I^{*}$ & $60^{*}$ & $60^{*}$ & \\
\hline & b. $p-v-t-x$ of solids & $2(3)$ & A & $\mathrm{U}, \mathrm{N}, \mathrm{I}$ & $1^{*}$ & $1^{*}$ & $60^{*}$ & $60 *$ & \\
\hline & c. thermodynamic parameters of solutions & 1 & A & $\mathrm{U}, \mathrm{N}, \mathrm{I}$ & $2\left(1^{*}\right)$ & $7\left(3^{*}\right)$ & $120\left(60^{*}\right)$ & $420\left(180^{*}\right)$ & \\
\hline & d. thermodynamic parameters of solids & 1 & A & $\mathrm{U}, \mathrm{N}, \mathrm{I}$ & 3 & 10 & 180 & 600 & \\
\hline & e. viscosity & $2(3)$ & A & $\mathrm{U}, \mathrm{N}, \mathrm{I}$ & $1^{*}$ & $2^{*}$ & $60^{*}$ & $120^{*}$ & \\
\hline & f. thermal conductivity & $2(3)$ & $A$ & $\mathrm{U}, \mathrm{N}, \mathrm{I}$ & $I^{*}$ & $2^{*}$ & $60^{*}$ & $120^{*}$ & \\
\hline & $\begin{array}{l}\text { g. electrical conductivity, acoustical } \\
\text { impendence, and magnetic susceptibility }\end{array}$ & $2(3)$ & A & $\mathrm{U}, \mathrm{N}, \mathrm{I}$ & $1^{*}$ & $2^{*}$ & $60^{*}$ & $120^{*}$ & \\
\hline & h. isotope equilibria & 1 & A & $U, \mathbb{N}, I$ & $0.5^{*}$ & $1.5^{*}$ & $30^{*}$ & $90^{*}$ & \\
\hline \multirow[t]{3}{*}{ c. } & Dissemination & & & & & & & & \\
\hline & Program coordinated and dissemination of data & 1 & A & $\mathbf{N}$ & 2 & 10 & 120 & 600 & 15 \\
\hline & TOTAL & & & & 13 & 42 & 780 & 2520 & 15 \\
\hline
\end{tabular}

*These efforts and funds have not been considered in the totals at the bottom of the columns. The evaluations will be performed at the beginning of experimental research or in the course of

model development 
IV. NATURAL SYSTEMS AND WATER-ROCK INTERACTION

\section{Introduction}

The chemical and physical processes involved in the exploitation of geothermal heat for energy production may be considered to occur in two principal environments: above ground, where energy is extracted from some heat exchange fluid; and below ground, where heat is concentrated and transferred to the heat exchange fluid. The surface environment is accessible to observation and more easily controlled. The underground environment can be observed only poorly at isolated points and is seldom, if ever, fully controllable. To utilize effectively geothermal resources, a better knowledge of the subsurface environment is needed. Only then may subsurface processes be partially controlled.

The information available of the subsurface geothermal environment comes from:

1. Waters and gases that flow to the surface and into drillholes where they can be sampled.

2. The one dimensional access to subsurface rocks and physical conditions afforded by drillholes.

3. The surface geology, which through geological experience, can be at least partially extrapolated underground.

4. The response of rocks and the underground environment with natural and artificial energy fluxes or forces - electrical, seismic, gravitational, magnetic, etc. (geophysics).

Chemists and geochemists are concerned mainly with 1,2 , and (to a lesser extent) 3. Geophysical data are extremely important and should be considered with chemical data in the study of geothermal systems but their generation and interpretation are outside the field considered by this panel. 


\section{A. Analytical Chemistry of Natural Materials: Waters, Gases, and Rocks}

The analytical chemistry of natural materials is fundamental to the understanding of geothermal systems. Chemistry of rocks can indicate broad geothermal targets. Chemistry of gases and waters of individual geothermal systems can indicate (1) the type of geothermal system (water or steam), (2) the temperature(s) of the geothermal aquifer(s), (3) the subsurface flow pattern for locating drillholes, and (4) possible problems with corrosion or scaling. Importance of individual components of waters and gases in geothermal prospecting is given in Table IV-I.

The large number of components in natural materials require a variety of analytical methods. New and improved methods should be fully exploited to reduce time and cost, and to make them available for field operation. For example, neutron activation of evaporates of water from wells and springs is capable of detecting about 50 elements, including gold and silver. This method measured the following average abundances of some of the elements in the water from a series of hot and cold springs in central Nevada (given in ppb unless ppm is indicated): $\mathrm{Na}-300 \mathrm{ppm}, \mathrm{Cl}-20 \mathrm{ppm}$, $\mathrm{W}-30, \mathrm{Mo}-2, \mathrm{Cs}-150, \mathrm{Rb}-130, \mathrm{Br}-70, \mathrm{Sb}-20, \mathrm{Ba}-130, \mathrm{U}$ (cold) 2, $\mathrm{Zn}-\sim 15$, and sometimes $\mathrm{Cr}-2 . \mathrm{Mg}, \mathrm{K}$, and $\mathrm{Ca}$ are also detected but the accuracy is better in soft $x$-ray fluorescence experiments. With the latter method, these waters were found to contain $\mathrm{Mg}-\sim 1 \mathrm{ppm}, \mathrm{Si}-50 \mathrm{ppm}$, $\mathrm{Ca}-50 \mathrm{ppm}, \mathrm{K}-30 \mathrm{ppm}$, and sometimes $\mathrm{S}$ and $\mathrm{P}$. Use of harder $\mathrm{x}$-rays would give values for $\mathrm{Sr}, \mathrm{Rb}$, and $\mathrm{Zr}$ as well as some other elements. With measurements on evaporates by isotope-shift Zeeman-effect atomic absorption, $\mathrm{Hg}, \mathrm{Pb}, \mathrm{Cd}$, $\mathrm{Se}, \mathrm{Bi}$, and also $\mathrm{As}$ and $\mathrm{Sb}$ can be searched for at levels of $0.01 \mathrm{ppb}$. Li and $\mathrm{B}$ at one $\mathrm{ppb}$ can be detected by emission spectroscopy. In general, the accuracies of the methods that are used are compromises with need to analyze a substantial number of samples, and they usually lie between 1 and $10 \%$.

Analyses of rock samples should be as complete as possible and include the major elements, most rate earths, the elements detected in the waters and in addition $\mathrm{Ta}$, Co, $\mathrm{Sc}$, Hf, $\mathrm{Th}, \mathrm{Ni}, \mathrm{Zr}$, and, of course, other elements that are suspected to be present. 
Table IV-1. Importance of individual components of water and gases in chemical study of geothermal systems

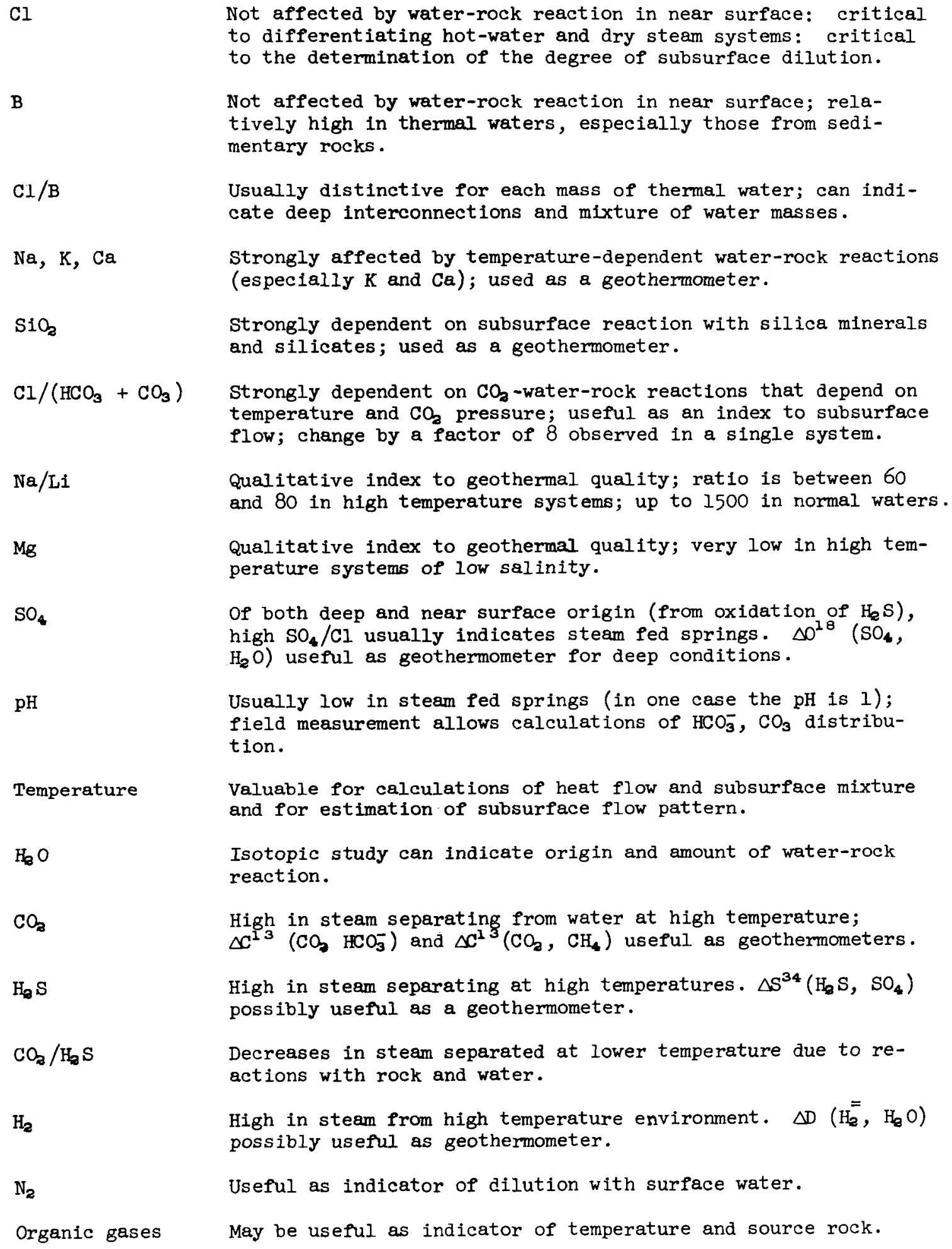

CI

B

$\mathrm{Cl} / \mathrm{B}$

$\mathrm{Na}, \mathrm{K}, \mathrm{Ca}$

$\mathrm{SiO}_{3}$

$\mathrm{Cl} /\left(\mathrm{HCO}_{3}+\mathrm{CO}_{3}\right)$

$\mathrm{Na} / \mathrm{Li}$

$\mathrm{Mg}$

$\mathrm{SO}_{4}$

$\mathrm{pH}$

Temperature

$\mathrm{H}_{6} \mathrm{O}$

$\mathrm{CO}_{3}$

$\mathrm{H}_{\mathrm{a}} \mathrm{S}$

$\mathrm{CO}_{2} / \mathrm{H}_{2} \mathrm{~S}$

$\mathrm{H}_{2}$

$\mathrm{N}_{2}$

Organic gases

Not affected by water-rock reaction in near surface: critical to differentiating hot-water and dry steam systems: critical to the determination of the degree of subsurface dilution.

Not affected by water-rock reaction in near surface; relatively high in thermal waters, especially those from sedimentary rocks.

Usually distinctive for each mass of thermal water; can indicate deep interconnections and mixture of water masses.

Strongly affected by temperature-dependent water-rock reactions (especially K and $\mathrm{Ca}$ ); used as a geothermometer.

Strongly dependent on subsurface reaction with silica minerals and silicates; used as a geothermometer.

Strongly dependent on $\mathrm{CO}_{3}$-water-rock reactions that depend on temperature and $\mathrm{CO}_{2}$ pressure; useful as an index to subsurface flow; change by a factor of 8 observed in a single system.

Qualitative index to geothermal quality; ratio is between 60 and 80 in high temperature systems; up to 1500 in normal waters.

Qualitative index to geothermal quality; very low in high temperature systems of low salinity.

Of both deep and near surface origin (from oxidation of $\mathrm{H}_{\mathrm{q}} \mathrm{S}$ ), high $\mathrm{SO}_{4} / \mathrm{Cl}$ usually indicates steam fed springs. $\triangle 0^{18}\left(\mathrm{SO}_{4}\right.$, $\mathrm{H}_{2} \mathrm{O}$ ) useful as geothermometer for deep conditions.

Usually low in steam fed springs (in one case the pH is 1); field measurement allows calculations of $\mathrm{HCO}_{3}^{-}, \mathrm{CO}_{3}$ distribution.

Valuable for calculations of heat flow and subsurface mixture and for estimation of subsurface flow pattern.

Isotopic study can indicate origin and amount of water-rock reaction.

High in steam separating from water at high temperature; $\Delta C^{13}\left(\mathrm{CO}_{3} \mathrm{HCO}_{3}^{-}\right)$and $\Delta C^{13}\left(\mathrm{CO}_{2}, \mathrm{CH}_{4}\right)$ useful as geothermometers.

High in steam separating at high temperatures. $\Delta \mathrm{S}^{34}\left(\mathrm{H}_{8} \mathrm{~S}, \mathrm{SO}_{4}\right)$ possibly useful as a geothermometer.

Decreases in steam separated at lower temperature due to reactions with rock and water.

High in steam from high temperature environment. $\Delta D\left(\mathrm{H}_{2}, \mathrm{H}_{8} \mathrm{O}\right)$ possibly useful as geothermometer.

Useful as indicator of dilution with surface water.

May be useful as indicator of temperature and source rock. 
The strategy of sampling in geothermal systems should be optimized. Cold water samples from each system must be collected and analyzed. Methods of preserving fugitive components for laboratory analyses should be developed.

Interlaboratory comparison of analytical methods should be encouraged and the problems of establishing and maintaining a geothermal water library of samples from drilled systems with known subsurface temperatures and rock types needs investigation along with those of a geothermal core library suggested later.

\section{B. Downhole Sampling and Measurement Technology}

Present drilling methods are poorly suited for the collection of data on geothermal systems. New drilling methods and equipment should be developed to allow acquisition of the maximum amount of information. These new drilling systems should provide (for slim holes) continuous core, fluid samples from defined horizons and intermittant temperature and pressure measurements at well bottom during drilling.

Production drilling systems should allow offset coring and fluid collection from packed-off zones.

Bore-hole geophysical methods should be routinely used in geothermal drilling. Special adaptations of standard methods will be needed for higher temperatures.

\section{Storage and Manipulation of Chemical Data on Geothermal Systems}

Data on geothermal systems and related information is being collected and stored in a computer by the Geothermal Resources Information and Data Center (GRID). This program should be encouraged and used. Other computer systems will be needed for the storage and manipulation of chemical data (see Sections III and $V$ ). 


\section{Isotope Studies}

Isotope studies have been found to be critical to the understanding of geothermal processes. Isotope analyses of water, dissolved constituents and gases can indicate (1) underground temperatures, (2) water sources, and (3) aquifer residence times. Isotope studies of solid materials can indicate the history of fluid temperatures and compositions. For these studies, stable isotopes of $\mathrm{O}, \mathrm{H}, \mathrm{C}, \mathrm{S}, \mathrm{Pb}$, and $\mathrm{Sr}$, and radioactive isotopes of $\mathrm{C}$ and $\mathrm{H}$ are of interest.

Isotopic age determinations are necessary in prospecting for broad geothermal targets such as large bodies of young silicic volcanic rocks.

\section{E. Solid Phases}

Altered and unaltered rocks of geothermal areas should be studied by the methods of mineralogy and petrology. Mineralogical relations can be an important guide to permeability and temperature. These mineralogic studies are basic to successful chemical modeling of geothermal systems (Section V).

Studies are needed on glass alteration reactions and the reactions of alkali and alkaline earths, feldspars, with and without quartz, micas, fluorite, carbonates, sulfates, amphiboles and pyroxenes as a function of salinity, $\mathrm{pH}$, redox, $\mathrm{p} \mathrm{CO}_{2}, \mathrm{p} \mathrm{H}_{2} \mathrm{O}$, temperature and pressure.

\section{F. Specialized Experimental Studies in Support of} Geothermal Systems Research

In addition to experiments to determine thermodynamic and kinetic properties of the phases found or produced in geothermal systems, there is a need for specialized experimental work including:

1. Laboratory calibration of the chemical and isotopic geothermometers (Table IV-2) that can give an indication of the quality of a geothermal field before drilling starts. This calibration must include knowledge of the kinetics as well as equilibrium of the thermometric reaction if the full potential of the methods are to be realized. 
2. Study of the rate of attainment of equilibrium in complicated multicomponent rock-water systems such as those involved in hydrothermal alteration.

3. Study of the effects of cooling pressure changes and partial vaporization on fluid compositions.

4. Study of the distribution of trace elements between water and minerals.

5. Study of the thermal stability of organic materials found in geothermal systems to see if additional information may be obtained.

In rock-water experiments it is important to use large ratios of rock surface area to water, and to start with compositions close to those of natural systems. The final products may exist in such small quantities that special methods such as surface spectroscopy and scanning electron microscopy will be necessary for their characterization.

The isotope geothermometers because of their relatively slow reaction rates are important for the study of the deeper parts of geothermal systems. The equilibrium and kinetic study of these reactions is especially important.

The isotope systems needing equilibrium calibration of kinetic study for use as geothermometers are

\section{Equilibrium $\quad \underline{\text { Kinetics }}$}

$\begin{array}{llll}\Delta C^{13} & \left(\mathrm{CO}_{2}, \mathrm{CH}_{4}\right) & \mathrm{x} & \mathrm{x} \\ \Delta D & \left(\mathrm{CH}_{4}, \mathrm{H}_{2}\right) & \mathrm{x} & \mathrm{x} \\ \triangle D & \left(\mathrm{H}_{2}, \mathrm{H}_{2} \mathrm{O}\right) & \mathrm{x} & \mathrm{x} \\ \triangle \mathrm{D} & \left(\mathrm{CH}_{4}, \mathrm{H}_{2} \mathrm{O}\right) & \mathrm{x} & \mathrm{x} \\ \Delta \mathrm{C}^{13}\left(\mathrm{CO}_{2}, \mathrm{HCO}_{3}^{-}\right) & & \\ \Delta 0^{38}\left(\mathrm{SO}_{4}^{=}, \mathrm{PO}_{4}^{-3}\right) & \mathrm{x} & \mathrm{x}\end{array}$

\section{G. Organics}

Organic materials are in both fluids and rocks in geothermal areas. They are contained in the original rocks or are the product of decomposition or reaction of these contained compounds with the induced thermal and chemical environment. Studies should include: 
Fluid

a. Hydrocarbon gases (all isomers)

b. Amines

c. Carboxyllic acids

$\underline{\text { Rocks }}$

a. Protein

b. Carbohydrates

C. Fats 
Table IV-2. Natural systems and rock-water interaction

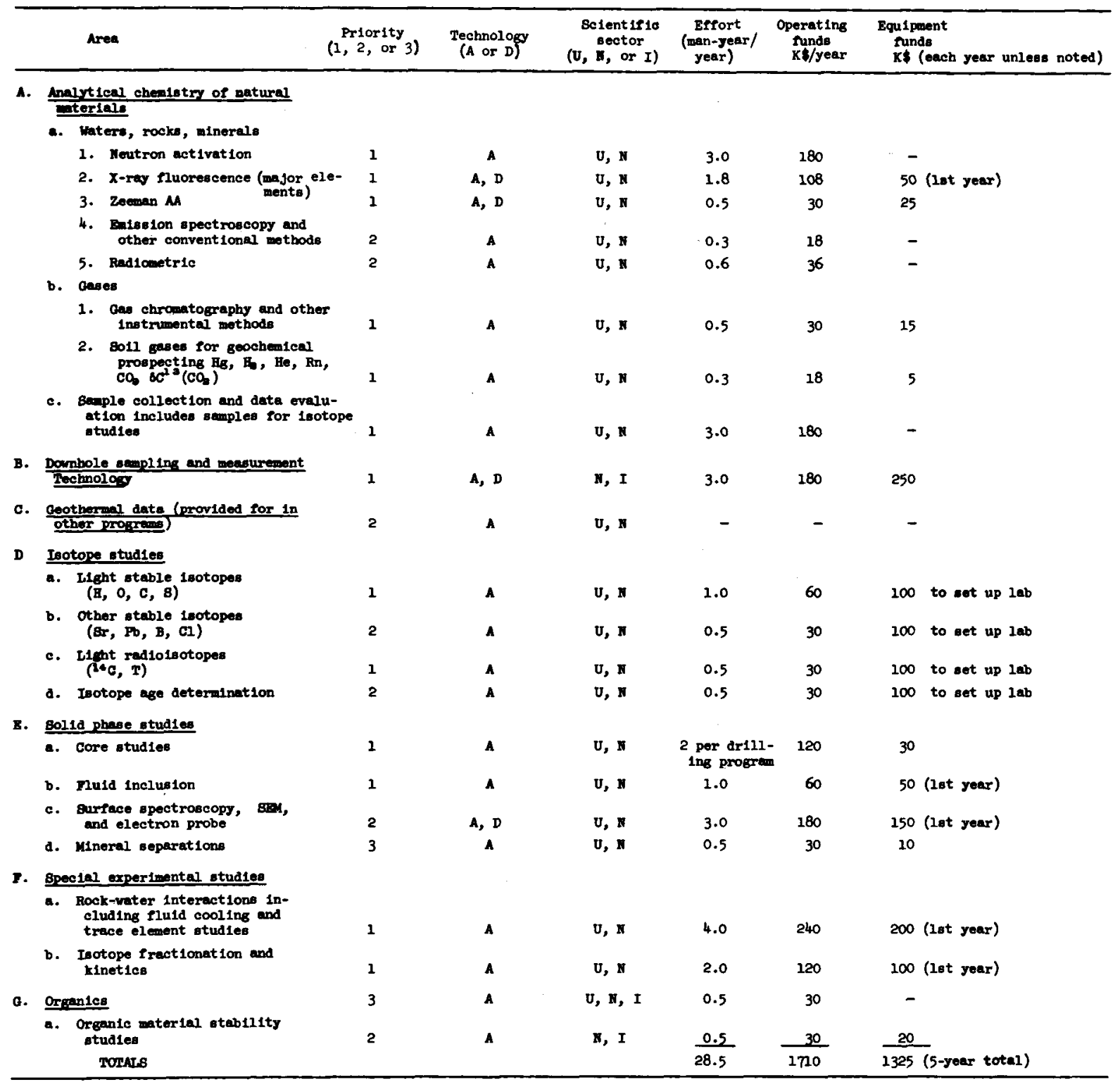

Iey: A avallable technology

D technology to be developed.

I induntrial

i national laboratory

U universally 
V. THEORETICAL MODELING OF GEOTHERMAI SYSTEMS

\section{Introduction}

Theoretical and modeling work is essential to the geothermal energy program in at least two aspects. First, as noted by the Panel on Thermodynamic and Physical Properties of Brines, Minerals, and Metals:

"Since the number of materials and combinations of materials is large, it is impractical to make detailed measurements on all of them. Theories or models, based on a relatively few key measurements and which can then be used for prediction, must be developed."

This need for prediction comes at a sequence of levels. First is the need to predict the properties of relatively simple substances or systems from sound theories or from models calibrated by similar systems for which measurements are available. Included in this category is the need to predict properties at different temperatures or pressures. These predictions are needed because the multiplicity of substances, systems, temperatures, and pressures is so great that a complete array of direct measurements is impractical even though any single quantity can be measured.

Without sharp distinction, one progresses to more complex systems, such as a complex multicomponent solution (or brine) emerging from a geothermal well, and eventually to the extremely complicated situation underground where aqueous solution interacts with a complex array of solid minerals. Especially in this final, underground situation, it is practically impossible to obtain experimentally all relevant information; and theoretical modeling is essential for the interpretation of observations and the guidance of exploration.

\section{Proposed Program}

Theoretical solutions to these problems will make full use of thermodynamics and similarly established general principles but much more is required. While there is no sharp devision, it is useful to discuss these needs at two levels: subsystems and complete systems. 


\section{Subsystems}

The "subsystems" in this sense include properties of single substances or of simple or moderately complex systems. Accurate experimental data are or should become available to check the validity of the theories or models for at least a few examples. While much existing knowledge is applicable, it is far from adequate. Recent work of Helgeson and associates on properties of water and on molal volumes of solutions and that of Pitzer and associates on thermodynamic properties, especially activity coefficients, of mixed as well as pure electrolyte solutions contribute in this area. Such work should be extended as rapidly as feasible to cover the range of substances, properties, and conditions of interest in geothermal systems. This activity will contribute to the evaluation of thermodynamic parameters for solutions.

Some further progress can be made by empirical equations based on available experimental data and general principles. But improved theoretical methods (or models) are needed to deal reliably and efficiently with many of these problems. Hence, the program should include basic as well as more directly focused work.

Advances in this "subsystems" section for both solid phases and aqueous phases are essential for the success of the program for "complete systems." This is discussed further under "Additional Comments."

\section{Complete Systems}

Currently, a modified version of a computer program originated by Helgeson is used to predict the extent to which components in a system are redistributed by geochemical processes. Thermodynamic principles are integrated with those of solution chemistry to formulate quantitative relations among irreversible and reversible processes of interest.

Differential equations describe dissolution of a reactant, precipitation of product minerals, oxidation-reduction reactions, binary solid solutions and changes in activity coefficients in either open or closed systems. These equations are expressed in matrix form and solved stepwise until total equilibrium or reactant disappearance occurs. Predictions concerning the extent to which minerals are produced and consumed, compositional changes 
in solid and aqueous phases and residstribution of species at constant temperature and pressure are computed at every step along the reaction path.

An aggressive computer modeling program would on attainment of its objective

- provide chemical information necessary for geothermal exploitation,

- interpret laboratory and field experiments,

- reduce to a minimum the number of experimental determinations,

- suggest leach mining possibilities,

- estimate radioactive distributions resulting from previous underground tests.

New and improved chemical and numerical techniques will be necessary before the program has the reliability and flexibility needed to reach these goals.

We recognize this proposal is an ambitious one, and unexpected results or problems may suggest or force shifts of emphasis among the areas outline below. Nevertheless, the results should not only have the intended utility but should also make significant contributions to the field of geochemistry in general.

\section{Additional Comments}

Additional comments follow on the status of input data for the complete system and the numerical analysis required.

Solid phases. Presently, a program library permits calculations on systems involving 131 minerals and solid solutions. However, more work should be done with the data base. Some of the thermodynamic data are questionable because of inadequate experimental data at the temperatures of interest or because of extrapolations based on poorly defined correlations. The data library should be updated frequently to include the best available thermodynamic data. Recognizing the difficulty of obtaining all the data experimentally, development of theoretical or empirical correlations should be encouraged. Groups of similar geometry such as rings, chains, sheets, etc., can be examined for additivity of their free energy contributions. 
Aqueous phases. At present, data for 128 aqueous species for temperatures up to $300^{\circ} \mathrm{C}$ at one atmosphere are available. The last review occurred in 1969 so there is a need for an update. Also, improved theoretical methods and models will make possible both improved accuracy and simpler calculations.

Improvement and extension of calculational program. There are many aspects of the presently available computer codes where improvement or simplification is needed. For example, the treatment of kinetic effects should be improved. For open systems, consideration should be given to the inclusion of chromatographic transport equations to predict relative velocities and shapes of replacement fronts. Provision should be made to sum all heat effects including those from chemical reactions. The effect of change of mass of liquid solvent (because of evaporation or dilution) should be treated more effectively.

Numerical analysis. Success with these computer experiments will depend on inputing reliable thermodynamic data, good chemical intuition and efficient numerical methods for computing equilibrium compositions. Such compositions are found either by searching for a minimum in free energy composition space or determining a numerical solution to a set of nonlinear equations. Both approaches compute a final equilibrium state from an initial set of conditions. Because geochemical systems are path dependent, equilibrium compositions must be found at each step of the reaction path. This is equivalent to solving a complex equilibrium problem at each step. Such a calculation requires a large computer and appreciable time. Running time can be reduced by decreasing the number of steps and/or increasing the computational efficiency of determining equilibrium concentrations. Variable step-size, predictor-corrector methods should be investigated as a means of reducing the number (presently over a thousand) of steps. Preliminary efforts using a piece-wise, fourth order, extrapolating polynomial between phase boundaries are encouraging and should be extended to other orders.

In general, chemical problems yield nearly full matrices for which special techniques are unavailable. Until more sophisticated numerical methods become available, emphasis on efficient LU decomposition routines should be stressed. 
A condition number analysis for a typical geochemical problem finds a minimum loss of accuracy of ten digits and a maximum loss of a full word. The consequences of this loss in accuracy should be a high priority item in this proposal.

Other mathematical modeling efforts (currently at LBL), which are aimed at solving only the transport of heat and fluids, should be adapted, if feasible, to include the geochemical solution processes described avove. A successful combination of these numerical methods would then provide a means of following the movement of heat and fluids in a geothermal system as well as the question of precipitation or dissolution of chemical species. 
Table V-1. Theoretical modeling of geothermal systems

\begin{tabular}{|c|c|c|c|c|c|c|}
\hline Specific analysis & Priority ${ }^{a}$ & Technology & $\begin{array}{l}\text { Scientific } \\
\text { sector }\end{array}$ & $\begin{array}{l}\text { Effort } \\
\text { (SMY) }\end{array}$ & $\begin{array}{l}\text { Operating } \\
\text { funds }\end{array}$ & Equipment \\
\hline $\begin{array}{l}\text { Aqueous phases (including } \\
\text { activity coefficients, } \\
\text { water activity, and } \\
\text { complex ion constants) }\end{array}$ & 1 & $\therefore \& D$ & $\mathrm{U}, \mathrm{N}$ & $\left\{\begin{aligned} 4 & \text { (1st } y r) \\
13 & \text { total }\end{aligned}\right.$ & $\left\{\begin{array}{l}240 \\
780\end{array}\right.$ & - \\
\hline $\begin{array}{l}\text { Solid solutions and } \\
\text { disordered phases }\end{array}$ & 1,2 & $A \& D$ & $\mathrm{U}, \mathbb{N}$ & 6 & 360 & - \\
\hline $\begin{array}{l}\text { Improvement and extension } \\
\text { of calculations I program }\end{array}$ & 1,2 & $A \& D$ & $\mathrm{U}, \mathrm{N}$ & 5 & 300 & - \\
\hline Numerical analysis & 1 & $A \& D$ & $\mathrm{U}, \mathrm{N}$ & 4 & 240 & - \\
\hline Totals for 5-year period & & & & 28 & 1680 & 0 \\
\hline
\end{tabular}

*Under priority 1,2 means first priority for about half of the program. 
DISCUSSION ON GEOTHERMAL CHEMISTRY

Lawrence Berkeley Laboratory

June 19, 1974

\section{$\underline{\text { Attendees }}$}

John P. Balagna

Harry R. Bowman

Frank Dickson

Robert 0. Fournier

Alvin $\mathrm{J}$. Hebert

Harold C. Helgeson

Calude C. Herrick

Charles E. Holley

Dennis D. Keiser

Gerhard Klein

George A. Kolstad

Richard N. Lyon

William L. Marshall

Robert E. Mesmer

Richard L. Miller

Kenneth S. Pitzer

Leonard F. Silvester

Alfred H. Truesdell

Theodore Vermeulen
LASL

LBL

Consultant

USGS - Menlo Park, CA

LBL

UC - Berkeley

I.ASL

LASL

Aerojet

SWCL - UC

AEC (Washington) DPR

ORNL

ORNL

ORNL

Aerojet Nuclear Co.

UCB/LBL

LBL

USGS - Menlo Park, CA

UCB/LBL 
JuIy 22, 1974

\section{Attendees}

Frank Asaro

LBL

John P. Balagna

LASL

George Barton

LLL

Harry R. Bowman

LBL

Charles L. Christ

USGS - Menlo Park, CA

Frank Dickson

Consultant

Robert 0 . Fournier

USGS - Menlo Park, CA

John L. Haas, Jr.

USGS - Reston, VA

Alvin J. Hebert

LBL

Harold C. Helgeson

UC - Berkeley

Claude C. Herrick

LASI

Gary Higgins

LIL

Charles E. Holley

LAST

Everett $H$. Jenne

Gerhard Klein

George A. Kolstad

Robert Lim

Richard N. Iyon

USGS - Menlo Park, CA

SWCL - UC

AEC/DPR

LLL

ORNL

William L. Marshall

ORNL

Robert E. Mesmer

ORNL

Richard L. Miller

Aerojet Nuclear Co.

Kenneth S. Pitzer

UC - Berkeley and LBL

R. N. Schock

IIIL

Leonard F. Silvester

LBL

Alfred H. Truesdell

USGS - Menlo Park, CA

Theodore Vermeulen

UC - Berkeley and LBL

Paul A. Witherspoon

LBL 